\title{
Natural Potential for Erosion for Brazilian Territory
}

\author{
Alexandre Marco da Silva ${ }^{1}$, Clayton Alcarde Alvares ${ }^{2}$ \\ and Claudia Hitomi Watanabe ${ }^{1}$ \\ ${ }^{1}$ Environmental Engineering Department - UNESP - Campus Experimental de Sorocaba \\ Altos da Boa Vista, Sorocaba - SP \\ ${ }^{2}$ Forestry Science and Research Institute - \\ Monte Alegre, Piracicaba - SP \\ Brazil
}

\section{Introduction}

Erosion and sedimentation refer to the motion of solid particles, called sediment (Julien, 2010). Erosion is a natural process and causes a breakdown of soil aggregates and accelerates the removal of organic and mineral materials (Gilley, 2005).

Soil erosion risk can be assessed by means of equations empirically derived from the superposition principle of this phenomenon. Using such models, during the last decade, several initiatives have assessed the risk of soil erosion at the national, continental, and global levels (Terranova et al., 2009).

The use of geographic information system (GIS) enables the determination of the spatial distribution of the parameters of some soil loss predicting models, as the Universal Soil Loss Equation - USLE (Dabral et al., 2008). Every factor within the USLE is calculated by GIS, which is obtained from meteorological stations, topographic maps, land use maps, soil maps and results of other relevant studies. The spatial distribution of the soil loss of a certain region is given by multiplying factor map layers in the GIS. The spatial resolution of the data is an option of researcher, and should be considered the resolution of the Digital Elevation Model (DEM), soil map, satellite images, among other sources of information (Yue-Qing et al., 2008).

Land use is the only factor affecting erosion that can be modified to reduce soil loss potential (Gilley, 2005). However, if we do not consider the land cover and soil management, i.e., if we consider the interaction of rainfall, topography and soil, assuming that the soil is totally uncovered along wholly study area, we may predict the total soil loss amount or the Natural Potential for Erosion (NPE) for a considered area (Castro \& Valério Filho, 1997).

NPE might be used as a tool to show cartographically areas highly pre-disposed to erosion and the mathematic relation among PNE value and soil loss tolerance value. It might indicate the ideal CP factor to be used in determined region.

Brazil is largest South American country and the land use is far from to be conformable with land use capability. Hence, soil loss studies and researches are highly needed. On the other hand, a lot of studies have been developed in order to predict soil loss rates along Brazilian 
territory. Some of them use GIS technology (Beskow et al., 2009), some use hydrosedimentologic database, or others approaches (Tornquist et al., 2009). But such studies involve only a part of territory (a river basin, for example).

Considering the scarcity of database of a map that presents the Natural Potential for Soil Erosion through a specific mathematical model, this study aims elaborate the NPE map for entire Brazilian Territory considering the USLE approach.

\section{Soil degradation}

Soil erosion is a process inherent in landscape evolution. The intensity of soil erosion is governed by numerous natural and anthropogenic factors. Natural factors include soil, climate, vegetation, relief and other ecoregional characteristics (Lal, 2001).

Soils are more exposed to erosion for different reasons: inappropriate agricultural practices, deforestation, overgrazing, forest fires, and construction activities (Terranova et al., 2009). Erosion process has both on-site and off-site consequences. On-site consequences results in the loss of productive topsoil and other physical and chemical consequences. Furthermore, off-site problems, such as downstream sediment deposition in fields, floodplains and water bodies, are also very serious, with significant costs to society (Verspecht et al., 2011).

Land degradation may be defined as long-term adverse changes in soil properties and processes, leading to a loss of ecosystem function and productivity caused by disturbances from which land cannot recover unaided (Bai et al., 2008; Palm et al., 2007). Through such changes in soil properties and processes, soil degradation undermines the sustainability of many of the ecosystem services (Palm et al., 2007).

Among the kinds of degradation, Bai et al. (2008) list water erosion, wind erosion, nutrient depletion, salinity, contamination, physical as the principal ones. Among them, water erosion is responsible by more than a half of the degraded land along world and also in South America.

South American continent is a region with particular and expressive areas presenting high or very high vulnerability for water erosion (Figure 1). It presents average soil loss rates of $16.7 \mathrm{t} \mathrm{ha}^{-1} \mathrm{y}^{-1}$ that is significantly higher if compared to the world average of $11.5 \mathrm{t} \mathrm{ha}^{-1} \mathrm{y}^{-1}$ (Nam et al., 2003).

\section{Soil loss modelling}

Assessment of risk of erosion has traditionally been carried out by application of one of the many available mathematical models (Boardman et al., 2009). Considering that any model is a simplification of reality (Morgan \& Nearing, 2011) and, for some users, this creates an immediate theoretical issue, the approach here employed considers three elementary natural features involved in erosion process: climate, relief and soil.

This approach is the Natural Potential for Soil Erosion (NPE). NPE, or Potential Erosion Risk, is defined here as the inherent risk of erosion irrespective of current land use or vegetation cover (Grimm et al., 2002; Vrieling et al., 2002). The NPE map can be generated using a part of the USLE model. The USLE is:

$$
\mathrm{A}=\mathrm{R} \text { K L S C P }
$$

Where: $\mathrm{A}$ is the rate of soil loss $\left(\mathrm{t} \mathrm{ha} \mathrm{a}^{-1} \mathrm{y}^{-1}\right), \mathrm{R}$ is a factor for annual rainfall erosivity (MJ mm ha- $\left.\mathrm{h}^{-1} \mathrm{y}^{-1}\right), \mathrm{K}$ is a factor for soil erodibility $\left(\mathrm{t} \mathrm{h} \mathrm{MJ}-1 \mathrm{~mm}^{-1}\right), \mathrm{L}$ is a factor for slope length $(\mathrm{m})$, 
$\mathrm{S}$ is a factor for slope steepness (\%). $\mathrm{C}$ is the cropping management factor and $\mathrm{P}$ is conservation practices factor (Wischmeier and Smith, 1978; Beskow et al., 2009). The two last factors are dimensionless and LS, when managed jointly, are also dimensionless.

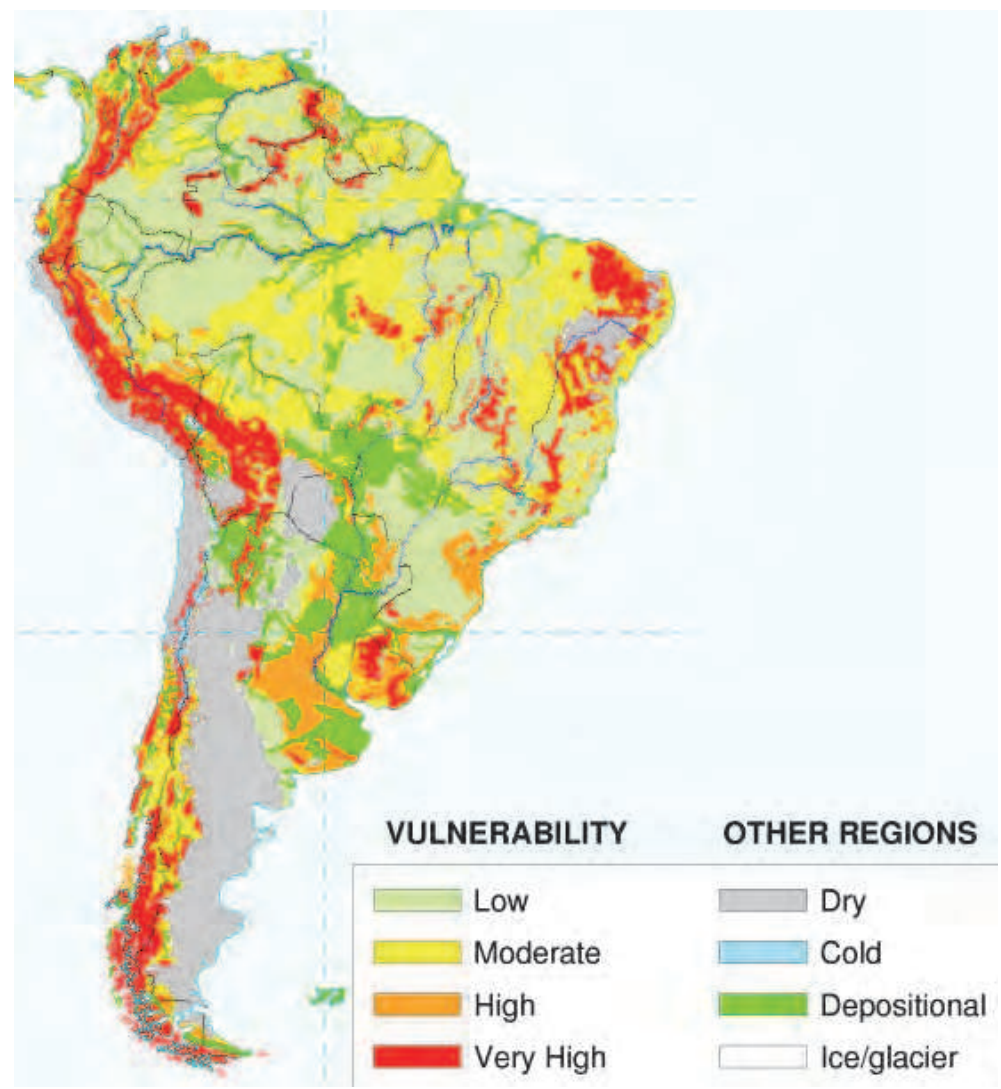

Fig. 1. Water erosion vulnerability map. Source: USDA (2003).

The NPE map is generated using the factors related to physical environment (rainfall erosivity, soil erodibility, and topographic factor). Factors $\mathrm{C}$ and $\mathrm{P}$, related to human influence (cover management and soil management), are not considered. So, the NPE model is:

$$
\mathrm{NPE}=\mathrm{R} \text { K LS }
$$

Where: NPE - Natural Potential for Erosion, in t.ha-1. $\mathrm{y}^{-1} ; \mathrm{R}, \mathrm{K}, \mathrm{LS}$ - same of equation (1).

\section{Brazilian environmental characteristics}

Brazil extends from the equatorial to the subtropical belt. Environmental characteristics are highly changeable along Brazilian territory due to large territorial size. The country is characterized by a large diversity of soil types, resulting from the interaction of the different 
relieves, climates, parent material, vegetation and associated organisms. This diversity and the consequent potential uses are reflected in the regional differences. There are nineteen major soil orders occurring along territory (Figure 2). The complex formed by the FAO System Xanthic, Rhodic and Haplic Ferralsols (named, according to Brazilian classification system (EMBRAPA, 2006), as Latossolos, and as Oxisols, according to Soil Survey Staff, 1999 ) is the predominant category and takes place in $38.7 \%$ of the Brazilian territory. The complex formed by the FAO System Rhodic and Haplic Acrisols and some Lixisols (named, according to Brazilian classification system (EMBRAPA, 2006), as Argissolos, and as Ultisols, according to Soil Survey Staff, 1999), is the second predominant category, taking place in $20.0 \%$ of the Brazilian territory. So, such two soil major classes represents more than a half of the Brazilian soils (FAO, 2004).

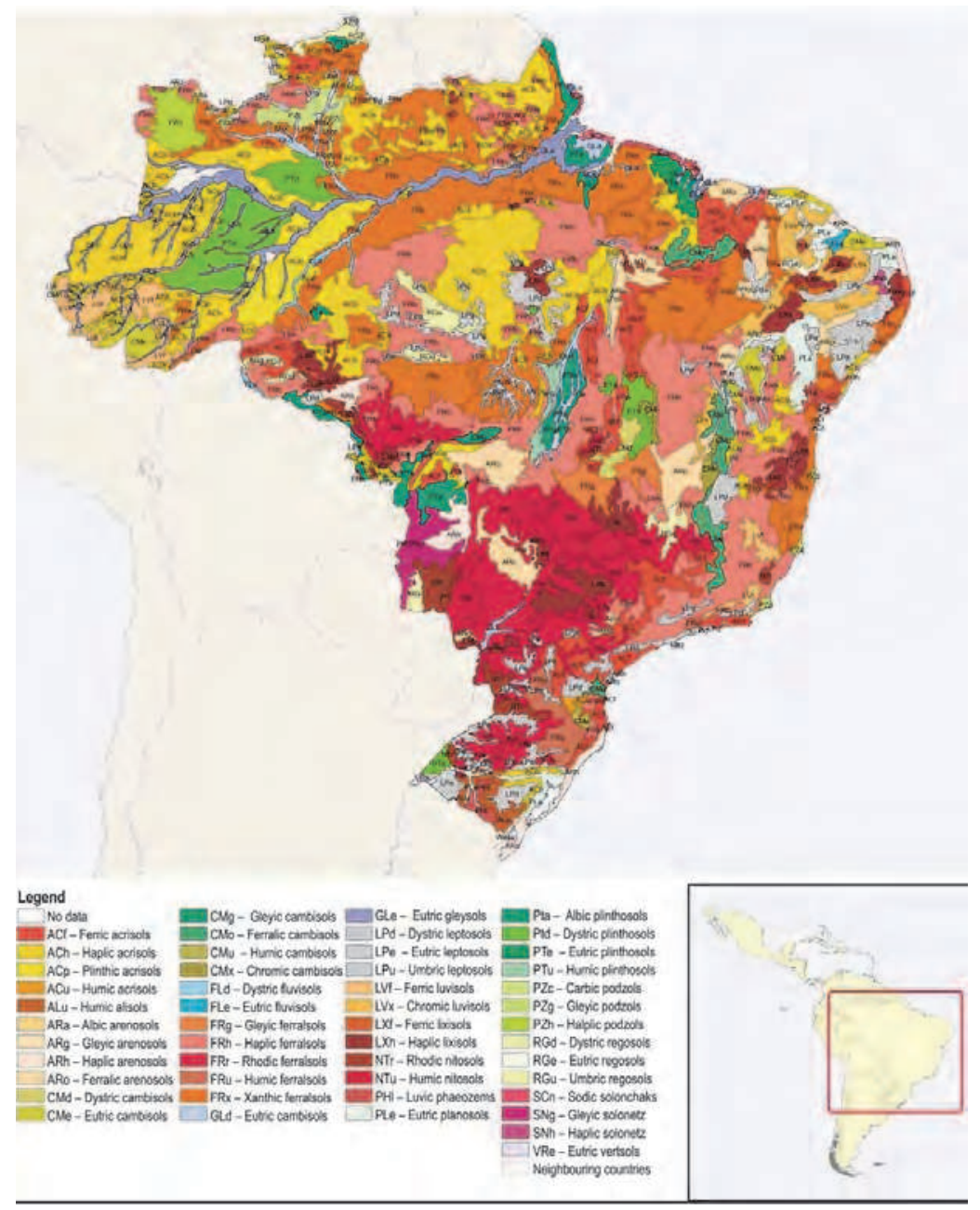

Fig. 2. Soil Classes occurring along Brazilian territory. Source: FAO (2004). 
The largest part of its eastern front is characterized by a morphoclimatic domain called "sea of hills", with convex upslope and rectilinear lower slopes, sometimes with benches or shoulders, sometimes concave by the colluvial accumulation. In southeastern and partly in the south, hills are preceded by the scarps of the Serra do Mar, which limits the Atlantic plateau (Cruz, 2000).

Figure 3 depicts the relief compartments, showing predominance of plain regions along Amazon region and predominance of plateaus mainly along southeastern and southern regions (IBGE, n.d.).

Three main groups of natural processes take place on the slopes of these humid tropical areas: (i) weathering-pedogenesis, forming thick weathered mantles reworked by; (ii) overland and sub-surface flow, and river flow; and (iii) mass movements, especially on scarped slopes, such as those of Serra do Mar and Serra da Mantiqueira, in the southeast, and the Serra Geral, in the south. Such natural processes vary according to geographic position, declivity, range and length of the scarps, as well as their geological nature, the thickness of alteration beds and climatic conditions (Cruz, 2000).

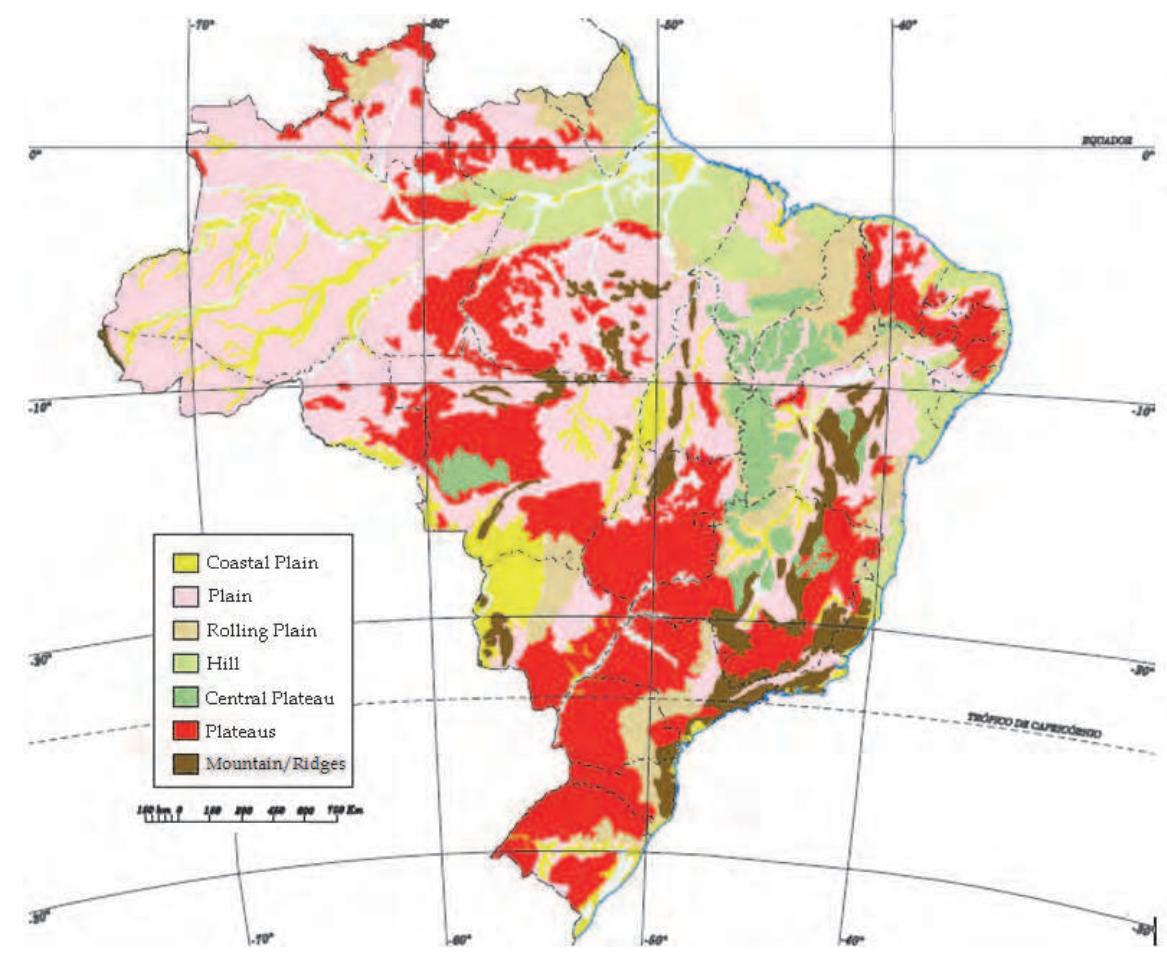

Fig. 3. Relief compartments map for Brazilian territory. Source: IBGE (n.d.) with legend translated according to map shown in Sayre et al (n.d.).

Climatologically, the minimal temperature (annual average values) ranges from 4 to $24^{\circ} \mathrm{C}$. Average temperature (annual average values) ranges from 8 to $30^{\circ} \mathrm{C}$. Maximum temperature (annual average values) ranges from 15 to $35^{\circ} \mathrm{C}$. In all cases, northern / northeastern regions present highest values, while southern region presents the lowest ones (INMET, n.d.). 
Driest areas occur in northeastern region, where annual rainfall amount is approximately $600 \mathrm{~mm}$. Northern region encompasses areas whose annual rainfall amount and erosivity are expressive (annual rainfall amount is usually over 2,500 mm), for example Amazon region (Silva, 2004). In most of Brazilian territory, annual rainfall depth ranges from 1,000 to 2,000 mm (Figure 4).

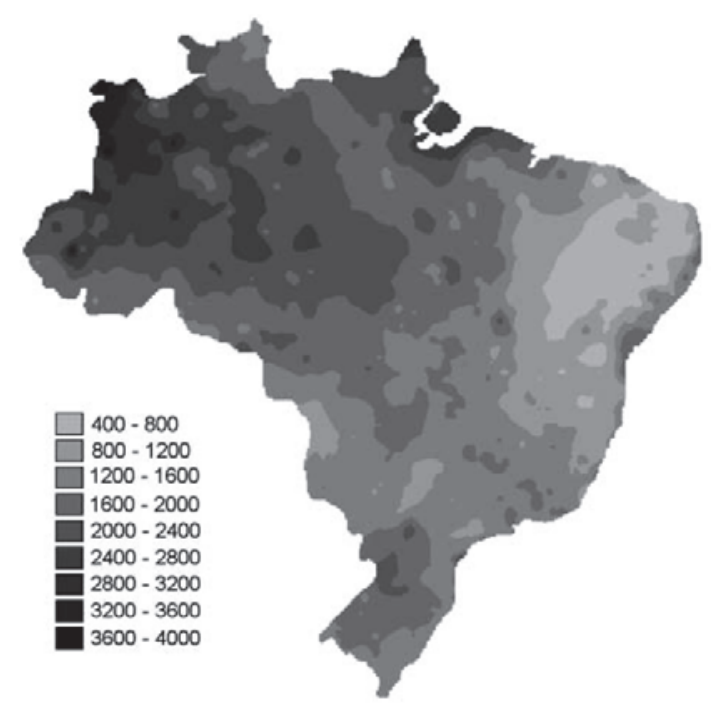

Fig. 4. Annual rainfall amount map of Brazilian territory (in mm. $\mathrm{y}^{-1}$ ). Source: Silva (2004).

\section{The natural potential for soil erosion map}

For each one NPE factor a single, separated layer was elaborated (Figure 5) and for each factor, a specific database was elaborated, as described below.

\subsection{R factor}

For $\mathrm{R}$ factor layer, we used the digital map of rainfall erosivity (Silva, 2004). In this study, the author considered eight majors Brazilian regions covering the whole of the territory of Brazil, and for each region, one adapted equation was applied using pluviometric records obtained from 1,600 weather stations with continuous database of at least twenty consecutive years.

\section{$5.2 \mathrm{~K}$ factor}

For K factor layer, a digital soil map (IBGE, 2001 and 2007) was considered. For determining the value of erodibility we used a soil profile database provided for whole Brazilian territory (Cooper et al., 2005). The erodibility was calculated indirectly through the method proposed by Boyoucos (1935), called clay-ratio method (Equation 3).

$$
\text { Erodibility }=[(\text { sand }+ \text { silt }) /(\text { clay })] / 100
$$

Where: erodibility expressed in t.h.MJ-1 $\mathrm{mm}^{-1}$ and the textural attributes expressed in $\mathrm{g} \cdot \mathrm{kg}^{-1}$. 


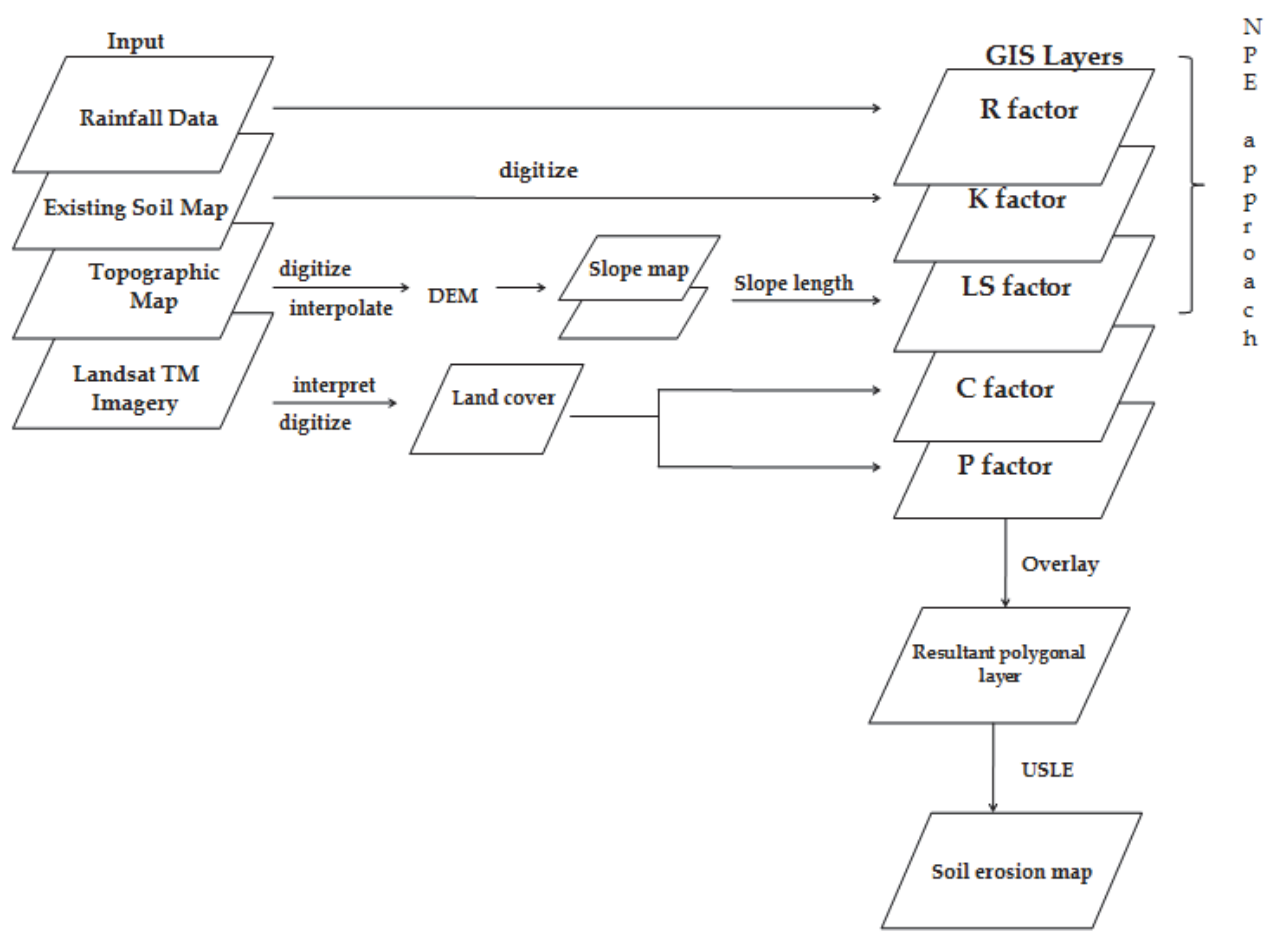

Fig. 5. Soil loss prediction through USLE approach and using GIS, modified from Mongkolsawat et al. (1994).

This equation is based only in textural characteristics of the soil. Due this simplicity and feasibility of obtaining, it is still largely used (Waswa et al, 2002, Lopes-Assad et al., 2009). We also used a complementary database regarding soil erodibility that occurs specifically along São Paulo State (Silva \& Alvares, 2005). Soil erodibility values were classified into five classes, as shown in Table 1 (Giboshi, 1999).

\begin{tabular}{l|r}
\hline Degrees of limitation & K Factor (t.h.MJ-1.mm ${ }^{-1}$ ) \\
\hline null & $\mathrm{K} \leq 0.010$ \\
weak & $0.010 \leq \mathrm{K}<0.020$ \\
moderate & $0.020 \leq \mathrm{K}<0.030$ \\
strong & $0.030 \leq \mathrm{K}<0.040$ \\
very strong & $\mathrm{K} \geq 0.040$ \\
\hline
\end{tabular}

Source: Giboshi (1999).

Table 1. Values and interpretation classes for soil erodibility.

Official Brazilian soil map (IBGE, 2001) was crossed with the soil erodibility map, and thus we obtained average values of the $K$ factor as large groups of Brazilian soils. For this, we used the tool "Zonal statistics as table" in GIS ArcMAP 10 (Theobald, 2007). 
Experimental semivariograms were determined until approximately $50 \%$ of the geometric camp, since after this value the semivariogram did not seem correct (Guerra, 1988), i.e., its accuracy was reduced due to a smaller number of possible pairs to calculate the semivariance at this distance. A geometric camp of 16 degrees (geographic coordinates) with partition groups (lags) of 1 degree was considered, as these lags are the estimators of the experimental semivariograms (Deutsch \& Journel, 1998). Theoretical models considered, such as spherical, exponential, Gaussian and linear, were described by Guerra (1988) and Andriotti (2003).

Only this theoretical semivariogram group was considered because it usually covers the general dispersion situation of soil science spatial events (Burrough \& McDonnell, 1998; Soares, 2006). Correlation coefficient of selected models were obtained through Cross Validation routine of the geostatistical software GS+, version 9. The spatial dependence index (SDI) was used according to Zimback (2001), which measures a sample's structural variance effect on total variance (sill). SDI comprises the following interpretation break: weak SDI $\leq 25 \%$, moderate SDI between $25 \%$ and $75 \%$ and strong SDI $\geq 75 \%$. This index is a complement of the traditional method recommended by Cambardella et al. (1994) in which the nugget weight effect (randomness) on total variance is evaluated. Through structural parameters obtained from experimental semivariograms, maps of some properties were created using GIS ArcMap v.10 (ESRI, 2010). A punctual ordinary kriging estimator was used for geostatistic interpolation.

\subsection{Topographic factor}

For LS layer (computed jointly), the Digital Elevation Model for Brazilian territory was obtained from SRTM project (Shuttle Radar Topography Mission) (Farr \& Kobrik, 2000), that it is in the fourth version (Jarvis et al., 2008). The LS map was generated through the algorithm available in Wischmeier and Smith (1978):

$$
\mathrm{LS}=(\lambda / 22.1)^{\mathrm{m}} *\left(0.065+0.045 \theta+0.0065 \theta^{2}\right)
$$

Where $\lambda=$ slope length (m); $\theta=$ slope gradient (\%); and $\mathrm{m}=0.5$ if the percent of slope is 5 or more, 0.4 on slopes of 3.5 to 4.5 percent, 0.3 on slopes of 1 to 3 percent, and 0.2 on uniform gradients of less than 1 percent.

The values of $\lambda$ and $\theta$ were derived from DEM (ESRI, 2010). For determination of $\lambda$ value we used the method proposed by Moore \& Burch (1986).

$$
\lambda=(\text { Flow Accumulation * Cell Size })
$$

Where: Flow Accumulation is a grid theme of flow accumulation expressed as number of grid cells (readily derived from watershed delineation processing steps) and Cell Size is the length of a cell side (m). Flow Accumulation was derived from the DEM, after conducting Fill and Flow Direction processes in ArcGIS 10 (Theobald, 2007; ESRI, 2010).

\subsection{NPE map}

Using Equation 2 and approach shown at Figure 5, the NPE layer was created. The final map was reclassified into interpretative classes. We analyzed which feature(s) influence(s) more expressively the spatial variability of the values of NPE along the study area. Hence, we interpreted the map considering the possibilities of aggravation of erosive process by present land use patterns which can be changed. 


\section{Results and discussion}

\section{1 $\mathrm{R}$ factor}

The annual rainfall erosivity ranges from 3,116 to 20,035 MJ mm ha-1 $\mathrm{h}^{-1}$ year-1 (Silva, 2004). The region with the lowest values is represented by the northeastern region and an occurrence in southeastern region. Highest values are found in the northern region, mostly in the Amazon region (Figure 6). Predominant class was "> 12,000 MJ mm ha-1 $\mathrm{h}^{-1} \mathrm{y}^{-1}$ " with $37.0 \%$ of occurrence (Table 2 ).

Spatial distribution of the rainfall amount and erosivity are irregular (Figures 4 and 6). In some regions the annual erosivity normally is incipient and others are extremely high (almost ten times more erosive than the areas with lowest erosivity). Maps elaborated by Rao et al. (1996) and showed in Figure 7 confirm this information. Such maps show that the trimester with major or minor contribution over seasonal distribution of amount of rain along Brazilian territory is also changeable.

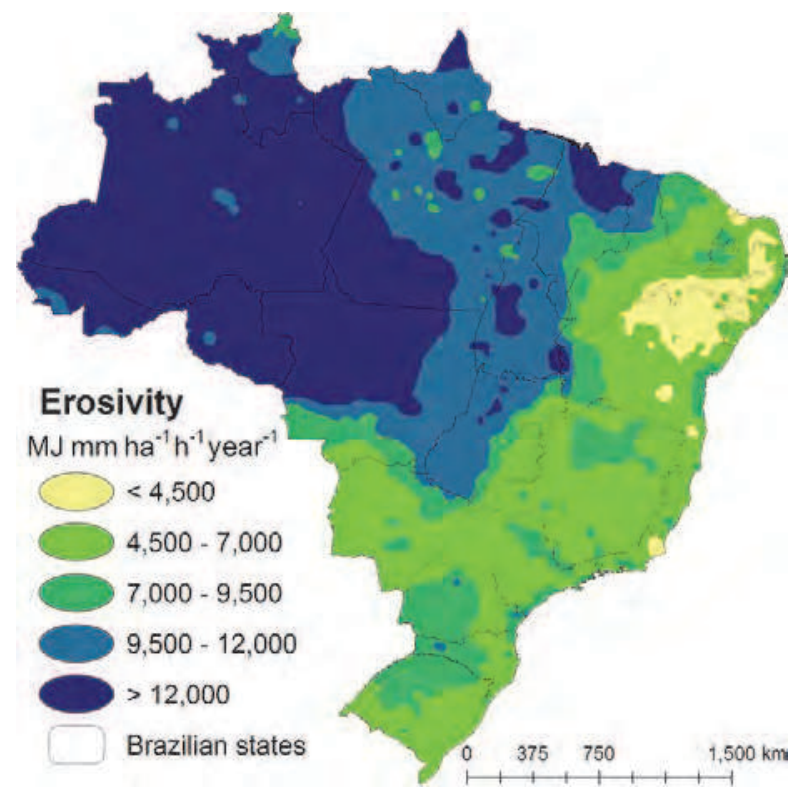

Fig. 6. Annual erosivity map (MJ mm ha-1 $\left.\mathrm{h}^{-1} \mathrm{y}^{-1}\right)$. Source: Silva (2004) - reclassified.

\begin{tabular}{lr}
\hline Erosivity (MJ mm ha-1 $\left.\mathrm{h}^{-1} \mathrm{y}^{-1}\right)$ & $\%$ \\
\hline$<4,500$ & 3.0 \\
\hline $4,500-7,000$ & 25.0 \\
\hline $7,000-9,500$ & 13.0 \\
\hline $9,500-12,000$ & 22.0 \\
\hline$>12,000$ & 37.0 \\
\hline
\end{tabular}

Table 2. Percentage of occurrence of each class of the R factor along Brazilian territory. 

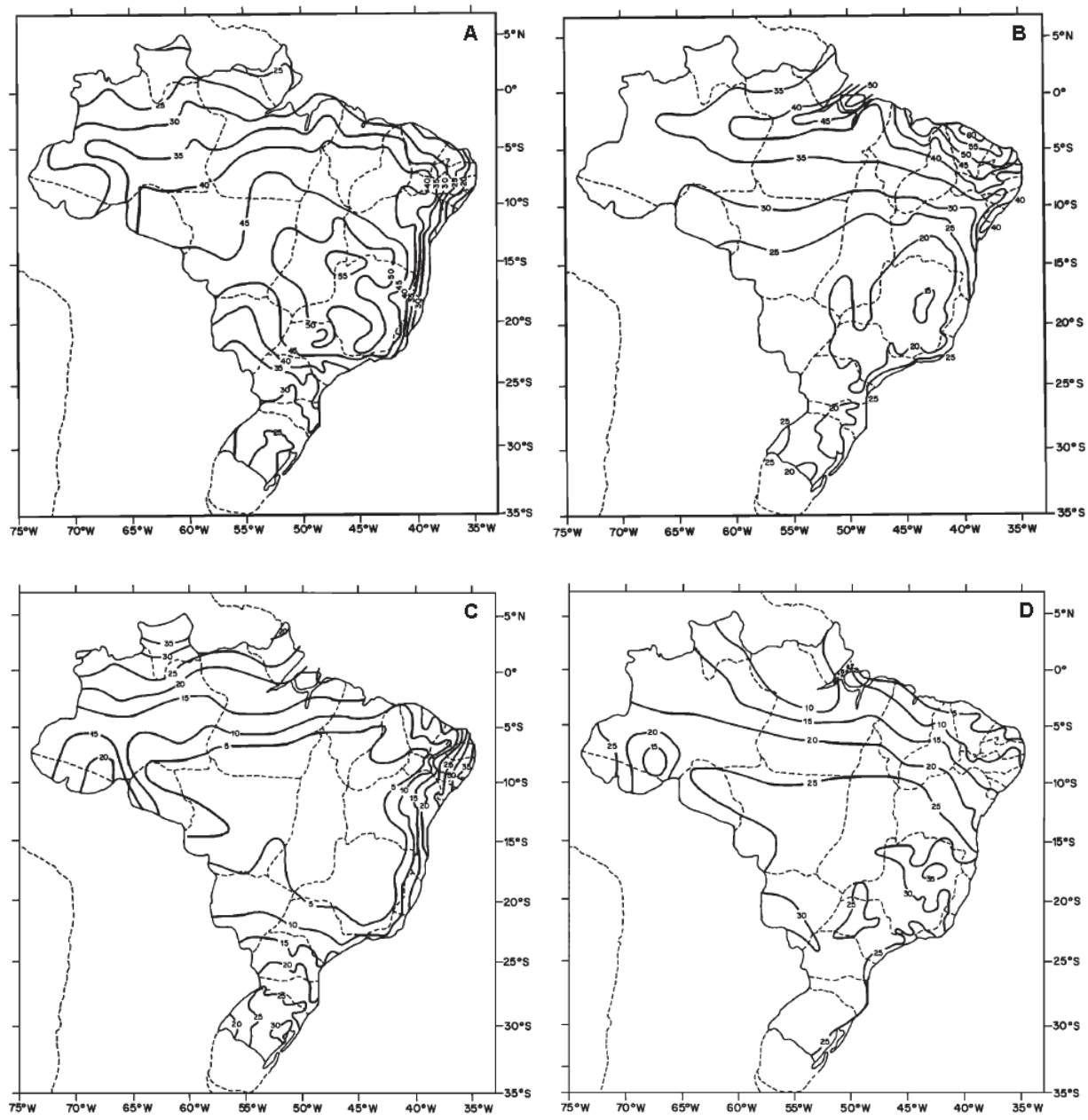

Fig. 7. Percentage contribution of trimester to the annual rainfall amount (A - December, January, February) (B - March, April, May) (C - June, July, August) (D - September, October, November). Source: Rao et al. (1996). For more details, see Rao et al. (1996).

\section{$6.2 \mathrm{~K}$ factor and semivariograms of soil texture}

Most of the Brazilian soils are highly erodibles, independently of climate and relief. This is supported by data of Figure 8 and Table 3. Classes with high erodibility (strong and very strong) occupy $53 \%$ of Brazilian territory. Soils classified as "very strong" occur mainly along northeastern and center-western Brazilian regions. For two states of the southern region (Paraná, Santa Catarina), the predominant occurrence is soils with low erodibility (green stain located in lower portion of the map). 


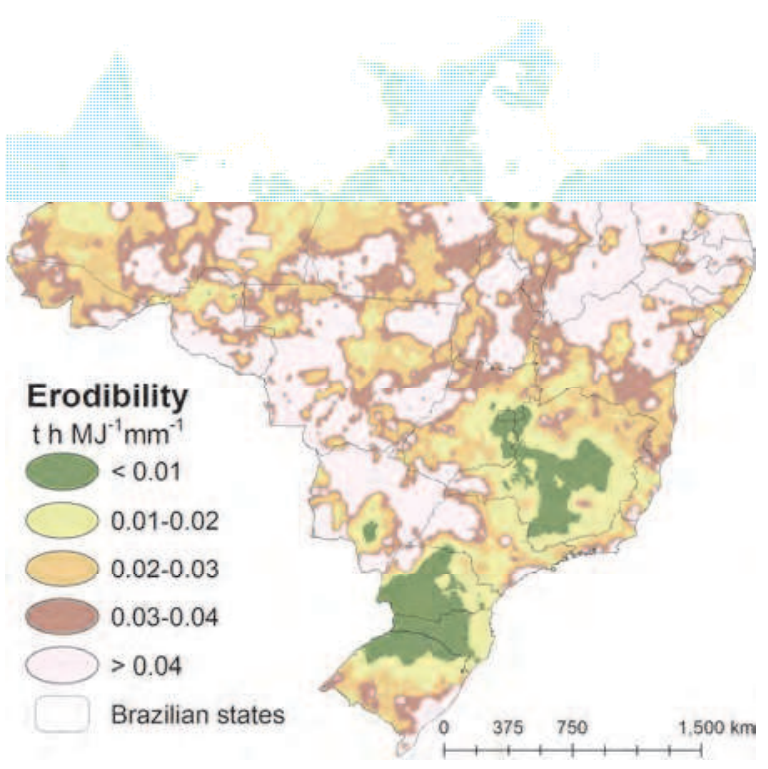

Fig. 8. Soil erodibility classes.

\begin{tabular}{lr}
\hline Erodibility classes & $\%$ \\
\hline null & 6.0 \\
\hline weak & 18.0 \\
\hline moderate & 23.0 \\
\hline strong & 20.0 \\
\hline very strong & 33.0 \\
\hline
\end{tabular}

Table 3. Percentage of occurrence of each class of the K factor.

The soil data were well fitted to an exponential theoretical model (Figure 9). They showed moderate SDI and the quality of cross-validation were considered normal for soil attributes (Vieira, 2000; Vieira et al., 2002).

According to database provided by Cooper et al. (2005), Brazilian soils are predominantly loam. It seems that soils with higher erodibility are related with high sand percentage than low clay percentage. The soils with high percentages of clay are concentrated mainly in southeastern and southern Brazilian regions. The second biggest stain of clay soils occurs on "Brazilian highlands" (see Figure 10 - left). On the other hand, soils with high percentages of silt are concentrated mainly in northern Brazilian region. Sandy soils occur mainly on the central region (nor in the northern or the southern region).

The estimated average values of erodibility of major groups of Brazilian soils are presented in Table 4. The Nitisols, Ferralsols and Histosols had the lowest average erodibility across their areas of occurrence, considered low erodibility. On the other hand, Regosols, Podzols, 
Planosols, Arenosols, Luvisols, are the highest average soil erodibility. According to Table 1 they are interpreted as soils of high erodibility. These results are similar to those obtained by Silva \& Alvares (2005), in State of Sao Paulo and Lino (2010), in State of Rio Grande do Sul.

\begin{tabular}{|c|c|c|c|}
\hline Embrapa $^{1}$ & $\mathrm{FAO}^{2}$ & Soil Survey Staff ${ }^{3}$ & $\mathrm{~K}\left(\mathrm{t} \mathrm{h} \mathrm{MJ} \mathrm{J}^{-1} \mathrm{~mm}^{-1}\right)$ \\
\hline Argissolos & Acrisols & Ultisols & 0.0374 \\
\hline Cambissolos & Cambisols & Inceptisols & 0.0353 \\
\hline Chernossolos & Chernozems & Molisols & 0.0287 \\
\hline Espodossolos & Podzols & Spodosols & 0.0736 \\
\hline Gleissolos & Gleysols & Entisols & 0.0344 \\
\hline Latossolos & Ferrasols & Oxisols & 0.0246 \\
\hline Luvissolos & Luvisols & Aridisols & 0.0478 \\
\hline Neossolos Flúvicos & Fluvisols & Fluvents & 0.0450 \\
\hline Neossolos Litólicos & Leptosols & Lithic & 0.0351 \\
\hline Neossolos Quartzarênicos & Arenosols & Quartzipsamments & 0.0534 \\
\hline Neossolos Regolítcos & Regosols & Psamments & 0.0791 \\
\hline Nitossolos & Nitisols & Oxisols Kandic & 0.0132 \\
\hline Organossolos & Histosols & Histosols & 0.0197 \\
\hline Planossolos & Planosols & Alfisols & 0.0650 \\
\hline Plintossolos & Plinthosols & Plintic & 0.0429 \\
\hline Vertissolos & Vertisols & Vertisols & 0.0374 \\
\hline
\end{tabular}

${ }_{1}^{1}$ Brazilian System of Soil Classification (EMBRAPA, 2006); ${ }^{2}$ World reference base for soil resources (FAO, 1998); ${ }^{3}$ Soil taxonomy (Soil Survey Staff, 1999).

Table 4. Computed K values for Brazilian soils in different classifications systems

\subsection{DEM and topographic factor}

More than a half of Brazilian territory presented LS factor values lower than 1 (Table 5). Class " $<1$ ", that occurs in $53.6 \%$ (Figure 10), was especially separated because locals presenting LS $<1$ mathematically represent diminution of the rates of soil loss and a possible opportunity for sediment deposition. For cells with LS values $=1$ there is no influence of the topography over soil loss, at least mathematically. For locals where the LS > 1 topography accelerates the erosion process. 

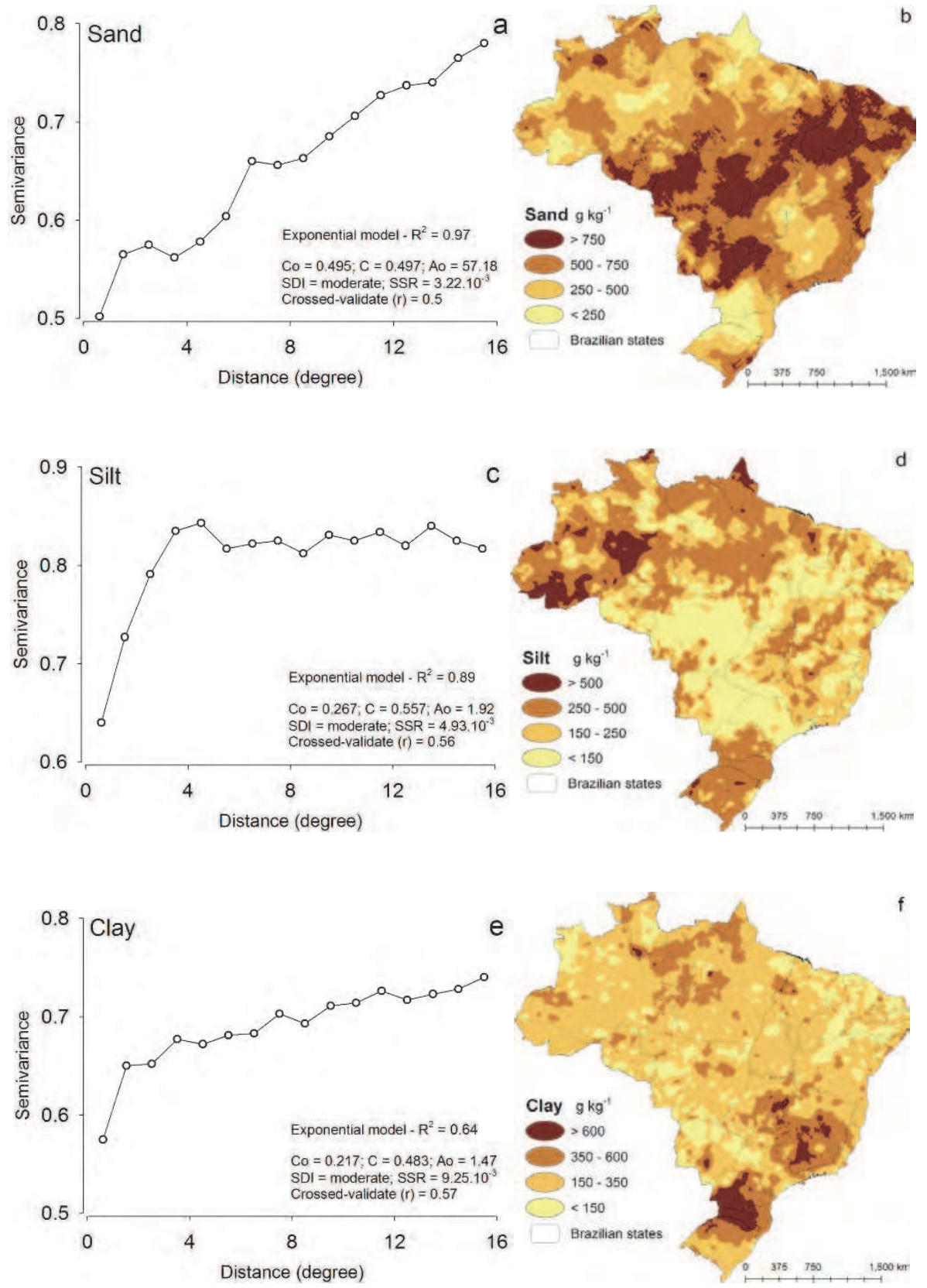

Fig. 9. Omnidirectional experimental semivariograms (sand, silt and clay) and maps of amount of sand (b), silt (d) and clay (f). 

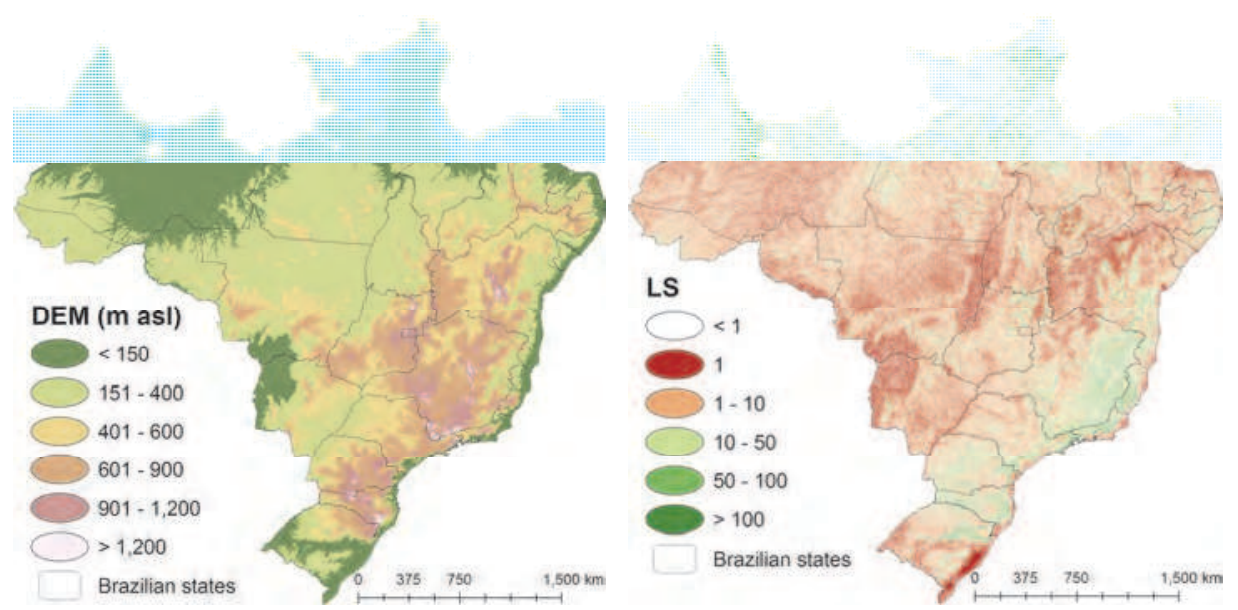

Fig. 10. Left: Digital elevation map for Brazilian territory (m). Right: map of LS factor values (dimensionless).

\begin{tabular}{lr}
\hline LS intervals & $\%$ \\
\hline$<1$ & 53.6 \\
\hline 1 & 13.5 \\
\hline $1-10$ & 23.6 \\
\hline $10-50$ & 7.8 \\
\hline $50-100$ & 1.1 \\
\hline$>100$ & 0.4 \\
\hline
\end{tabular}

Table 5. Percentage of occurrence of each class of the LS factor.

DEM presented in Figure 10 suggests that higher LS values are associated with high altimetric values. Such high LS values are more concentrated along mountainous regions (see Figure 3 - relief). Along Brazilian territory occur predominantly regions with low altimetry, due: (a) antique lithology, (b) no occurrence of modern geological folding, and (c) due to be situated in the core area of a tectonic plate called South America Plate (IBGE, n.d.). Some of hilly or scarped regions are located near the shoreline and in regions with high population concentration, as cities of Santos and Rio de Janeiro. The three classes that represent most severe topographic condition occur in $9.3 \%$.

\subsection{NPE map}

The integration of the three factors early described (R, K and LS) outcomes the NPE map, shown in Figure 11. Possibly due to relief influences, the predominant class was " $<200$ t.ha${ }^{1} \cdot \mathrm{y}^{-1}$ ", with $61 \%$. Surprisingly, the second major class was "> 1600 t.ha-1 $\mathrm{y}^{-1}$ ", with $14 \%$ (Table 6). Besides of the occurrence of soils highly erodibles along Brazilian territory, the geographical distribution of high values of NPE has two notable distinct influences. The first one is an evident influence of very high erosivity values ( $\mathrm{R}$ factor). The second one is major 
influence of relief (LS factors) in eastern portion. This information takes an important role on the establishment of land use politics in order to promote a sustainable land use, as rural or urban.

The pressure of population, among other factors, is leading to increased cultivation of tropical steeplands, generally defined as land with slope exceeding 20\% (Presbitero et al., 2005). Brazil is a typical case of this problem, especially for southeastern Brazilian region, where the land use is more intensive.

In rural context, many crops have been cultivated in hilly areas and favoring the erosion process. Coffee, orchards (orange) and sugar-cane sometimes cultivated in steep lands in São Paulo State are examples. On the other hand, areas currently used for grain production, especially soy-located in western region of the gaucho countryside, Mato Grosso do Sul and Mato Grosso, and the Central Plateau from Goias to Tocantins, generally correspond to those areas with a high potential for sediment production (Castro \& Queiroz Neto, 2010). However, Brazil has adopted over the last two decades the use no-tillage in agriculture, mainly soybeans and corn (Lino, 2010). In forestry, the sector employs mainly the technique of "minimum cultivation", which provides the least impact on soil (Gonçalves et al., 2000).

In urban context, in metropolitan regions like São Paulo, Rio de Janeiro, Belo Horizonte and Recife, there are a significant number of people living in sloped areas, characterizing risk areas. Catastrophic mass movements recorded in Brazil are concentrated in the southeastern (São Paulo, Rio de Janeiro, Minas Gerais, and Espirito Santo states) and southern (Rio Grande do Sul, Santa Catarina, and Paraná states) regions of the country. They are predominantly related to the occurrence of rainfall, that is of great intensity and short duration, and sometimes happen after rainy periods of long duration (Coelho-Netto et al., 2010).

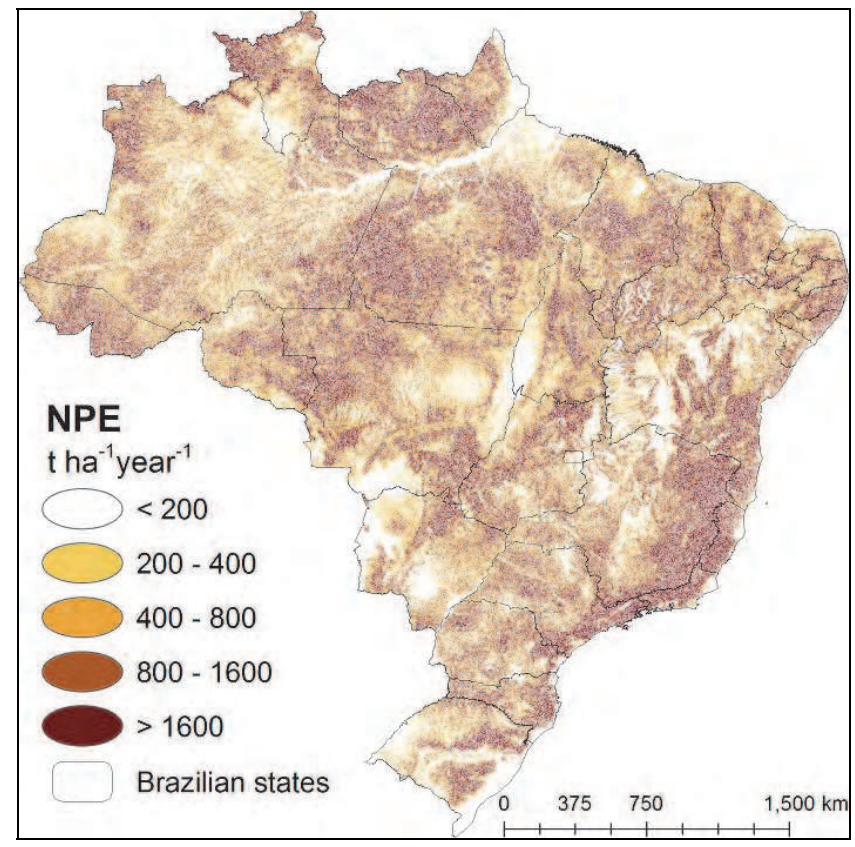

Fig. 11. NPE map for Brazilian territory. 


\begin{tabular}{lr}
\hline NPE & $\%$ \\
\hline$<200$ & 61.0 \\
\hline $200-400$ & 8.0 \\
\hline $400-800$ & 9.0 \\
\hline $800-1600$ & 8.0 \\
\hline$>1600$ & 14.0 \\
\hline
\end{tabular}

Table 6. Percentage of occurrence of each class of the NPE.

Table 7 shows a summary of the main types of land degradation found in Brazil (Zuquete et al., 2004). Many of them are strictly related to erosion process, alter the hydrologic balance, and present some (hydro)geomorphologic consequences according to kind of human interference. Associating the human interferences (consequences according to activity), the NPE map, and the population density map (Figure 12), it is possible perceive that the zone of $300 \mathrm{~km}$ from shoreline to west is probably the most "problematic" region of Brazilian territory, because there is high concentration with high NPE values and simultaneously high population density, with many kinds of interferences.

Today, more than $20 \%$ of the total dissolved and suspended mass delivered to the oceans comes from the Himalaya and the Andes, carried by three rivers: the Brahmaputra, Ganges and Amazon (Goddéris, 2010). As early informed, some areas surrounding the Amazon basin has high potential for sediment production (Castro \& Queiroz Neto, 2010), as well as the hilly areas located on southeastern Brazilian region (Figure 13).

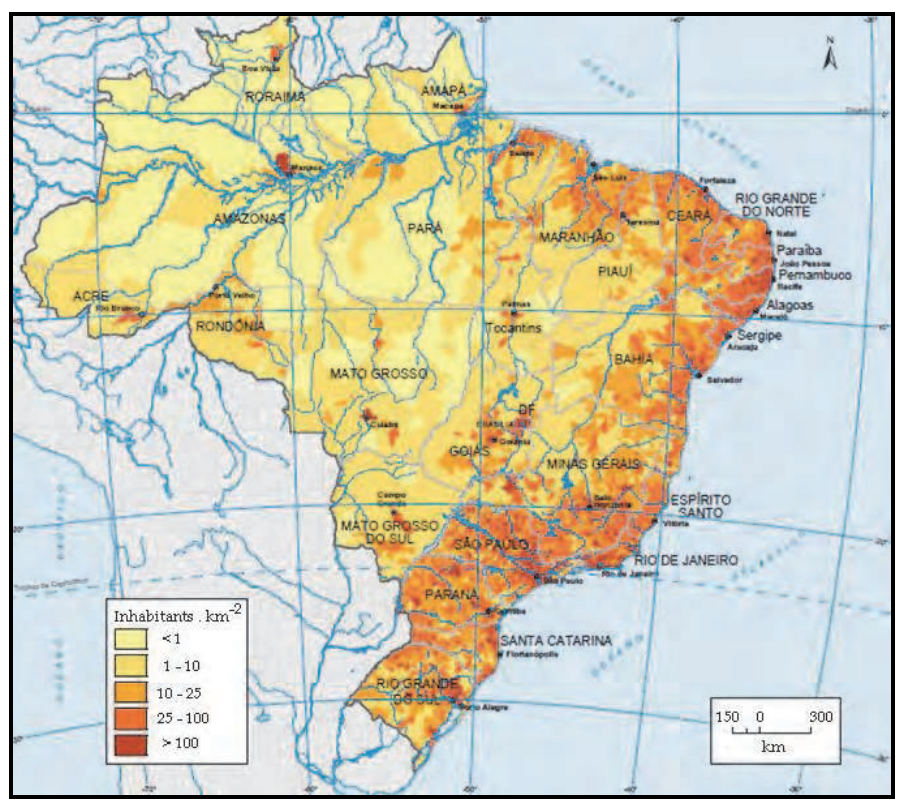

Fig. 12. Cartogram of Brazilian population density. Source: IBGE (n.d.). 


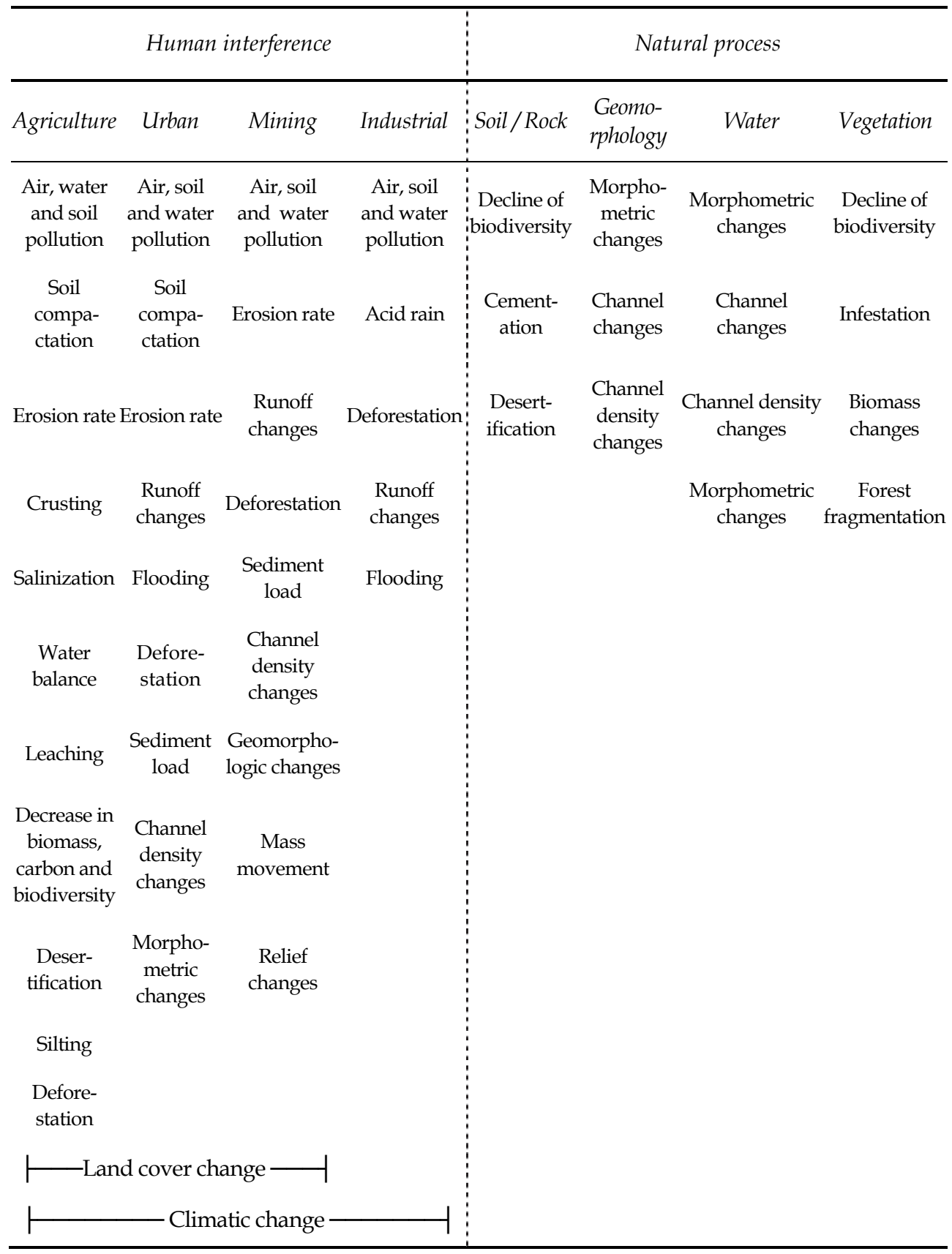

Source: Zuquette et al. (2004) - modified.

Table 7. Main types of land degradation found in Brazil. 


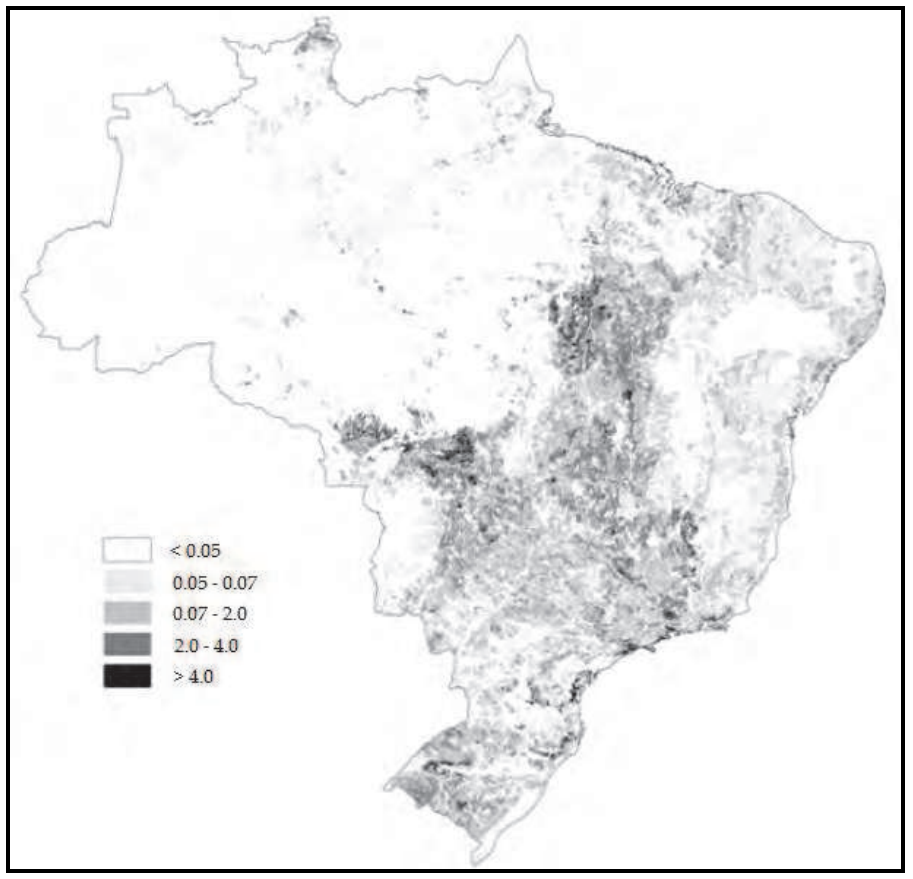

Fig. 13. Map of sediment yield in Brazil. Source: Castro \& Queiroz Neto (2010). Legend modified from t.km-2. $\mathrm{y}^{-1}$ to t.ha-1. $\mathrm{y}^{-1}$.

If we adopt the soil density value $1,200 \mathrm{~kg} \mathrm{~m}^{-3}$. and average rate of soil formation $-0.0002 \mathrm{~m}$ $\mathrm{y}^{-1}$ (Sparovek \& Schnug, 2001), we infer the maximum tolerable soil loss is 2.4 t.ha $\mathrm{a}^{-1} \cdot \mathrm{y}^{-1}$. Using equation 6 (Valerio Filho, 1994) it is possible estimating the recommended CP value(s) that is in accordance with sustainable principles of soil conservation, i.e., the annual soil loss rate is smaller or equivalent to average rate of soil formation.

Tolerable CP $=$ tolerable soil loss / NPE value

\section{Final considerations}

We reported here the NPE for Brazilian territory in a broad scale, especially for pedological cartographic database. As stated by Mendonça-Santos \& Santos (2007), at present, approximately 35\% of Brazil, 17 out of 26 states and the Federal District, is covered with soil maps at several intermediate scales $(1: 100,000-1: 600,000)$ and total coverage of the country is available at exploratory and schematic levels (scales 1:1,000,000 and 1:5,000,000).

In Brazil, soil surveys are still necessary, mainly at larger scales, to support evaluation of soil resources for planning, and management of agricultural and also for environmental projects. Detailed and semi detailed soil surveys are now available in small areas, to support localspecific agricultural and environmental projects (Mendonça-Santos \& Santos, 2007). This confirms a necessity for further studies in intermediate scales or preferably, in detailed scales, both for NPE as for actual soil loss. 
However, the study in such broad scale here presented permitted we found the major influences over the NPE values according to region of the Brazilian territory. Also, comparing the NPE map with population density, with specific sediment yield and with complementary bibliographic data, we identified major socio-environmental risk areas of NPE.

The great challenge is establish regional and local land use politics conformable with the average rate of soil formation. There are hundreds of cultivars that can be cultivated along the Brazilian territory according to local edaphoclimatic conditions. But they should be managed (both the cultivar and the soil) in order to reduce the soil loss to acceptable rates. The NPE is a tool that helps achieving this aim.

\section{Acknowledgments}

To Fapesp and Pró-reitoria de Pós-Graduação - Unesp, for financial support.

\section{References}

Andriotti, J. L. S. (2003). Fundamentos de Estatística e Geoestatística. Editora UNISINOS, São Leopoldo, RS, Brazil.

Bai, Z. G.; Dent, D. L.; Olsonn, M. E. (2008). Proxy global assessment of land degradation. Soil Use and Management, Vol.24, pp. 223 - 234.

Beskow, S.; Mello, C. R.; Norton, L. D.; Curi, N.; Viola, M. R.; Avanzi, J. C. (2009). Soil erosion prediction in the Grande River Basin, Brazil using distributed modeling. Catena, Vol.79, pp. 49-59.

Boardman, J.; Shepheard, .M. L.; Walter, E.; Foster, I. D. L. (2009). Soil erosion and riskassessment for on- and off-farm impacts: A test case using the Midhurst area, West Sussex, UK. Journal of Environmental Management, Vol.90, pp. 2578-2588.

Bouyoucos, G. J. (1935). The clay ratio as a criterion of susceptibility of soils to erosion. Journal of the American Society of Agronomy, Vol.27, pp. 738-741.

Burrough, P. A.; Mcdonnell, R. A. (1998). Principles of Geographical Information Systems. New York: Oxford University Press, $333 \mathrm{p}$.

Cambardella, C. A.; Moorman, T. B.; Parkin, T. B.; Karlen, D. L. (1994). Field-scale variability of soil properties in central Iowa soils. Soil Science Society of America Journal, Vol.58, pp. 1501-1511.

Castro, A. G.; Valério Filho, M. (1997). Simulação da expectativa de perdas de solo em microbacia sob diferentes manejos florestais. Revista Brasileira de Ciência do Solo, Vol.21, pp. $419-426$.

Castro, S. S.; Queiroz Neto, J. P. (2010). Soil Erosion in Brazil from Coffee to the Present-day Soy Bean Production, Pages 195 - 221. In: Latrubesse, E. M. Natural Hazards and Human-Exacerbated Disasters in Latin America. Developments in Earth Surface Processes. Elsevier, Vol 13, 510 pages.

Coelho-Netto, A. L.; Avelar, A. S.; Lacerda, W. A. (2010). Landslides and Disasters in Southeastern and Southern Brazil. Chapter 12, pages 223 - 243. In: Latrubesse, E. M. Natural Hazards and Human-Exacerbated Disasters in Latin America. Developments in Earth Surface Processes. Elsevier, vol 13, 510 pages. 
Cooper, M.; Mendes, L. M. S.; Silva, W. L. C.; Sparovek, G. (2005). A national soil profile database for Brazil available to international scientists. Soil Science Society America Journal, Vol.69, pp. 649-652.

Cruz, O. (2000). Studies on the geomorphic processes of overland flow and mass movements in the Brazilian geomorphology. Revista Brasileira de Geociências, Vol.30, pp. 504-507.

Dabral, P. P.; Baithuri, N.; Pandey, A. (2008). Soil Erosion Assessment in a Hilly Catchment of North Eastern India Using USLE, GIS and Remote Sensing. Water Resources Management, Vol.22, pp. 1783 - 1798.

Deutsch, C. V.; Journel, A. G. (1998). GSLIB: Geostatistical software library and user's guide. 2nd ed. Oxford University Press, New York, NY, USA.

EMBRAPA (Brazilian Agricultural Research Corporation). (2006). Brazilian System of Soil Classification. ${ }^{\text {nd }}$. Centro Nacional de Pesquisa de Solos, Rio de Janeiro, RJ, Brazil (in Portuguese).

E.S.R.I. (Environmental Systems Research Institute). (2010). Software of Geographic Information System, ArcGIS 10, Redlands, CA, USA.

F.A.O. (Food and Agricultural Organization). (1998). World reference base for soil resources. FAO: ISSS: ISRIC, Rome. (FAO. World Soil Resources Reports, 84).

F.A.O. (Food and Agriculture Organization). (2004). Fertilizer use by crop in Brazil. Ebook Access (March 29, 2011): ftp:/ ftp.fao.org/docrep/fao/007/y5376e/y5376e00.pdf

Farr, T. G.; Kobrick, M. (2000). Shuttle Radar Topography Mission produces a wealth of data. American Geophysical Union Eos, Vol.81, pp. 583-585.

Giboshi, M. L. (1999). Desenvolvimento de um sistema especialista para determinar a capacidade de uso da terra. MSc Dissertation. Faculdade de Engenharia Agrícola, Universidade de Campinas (Campinas - SP - Brazil), 77 p.

Gilley, J. E. (2005). Erosion water-induced, p. 463 - 469. In Hillel, D. Encyclopedia of Soils in the Environment. Elsevier Editor, 4 volumes and 2,200 pages.

Goddéris, Y. (2010). Earth Science: Mountains without erosion. Nature, Vol.465, pp. 169 171.

Gonçalves, J. L. M.; Stape, J. L.; Benedeti,V.; Fessel, V. A. G.; Gava, J. L. (2000). Reflexos do cultivo mínimo e intensivo do solo em sua fertilidade e na nutrição das árvores. p. 3-57. In: Gonçalves, J. L. M., Benedetti, V., eds. Nutrição e fertilização florestal. Forestry Science and Research Institute, Piracicaba, SP, Brazil.

Grimm, M.; Jones, R.; Montanarella, L. (2002). Soil Erosion Risk in Europe. European Soil Bureau - Institute for Environment and Sustainability. European Commission Joint Research Centre - Ispra. Revised Edition. Italy, 44 p.

Guerra, P. A. G. (1988). Geoestatística operacional. DNPM, Brasília, DF, Brazil.

I.B.G.E. (Brazilian Institute for Geography and Statistics). (2001). Soil map of Brazil. Scale: 1.5.000.000. Diretoria de Geociências. EMBRAPA Solos. Brasília, DF, Brazil.

I.B.G.E. (Brazilian Institute for Geography and Statistics). (2007). Manual Técnico de Pedologia, 2nd edition. 316 p.

I.B.G.E. (Brazilian Institute for Geography and Statistics). (n.d.). Mapa do site - Geociências. Access in April / 2011.

URL: http://www.ibge.gov.br/home/mapa_site/mapa_site.php\#geociencias

I.N.MET. (Brazilian Institute for Meteorology). (no data). Normais climatológicas do Brasil, de 1961 a 1990. URL: http:/ /www.inmet.gov.br/html/clima 
Jarvis, A.; Reuter, H. I.; Nelson, A.; Guevara, E. (2008). Hole-filled SRTM for the globe Version 4. Available from the CGIAR-CSI SRTM 90m Database: http://srtm.csi.cgiar.org.

Julien, P. Y. (2010). Erosion and sedimentation. $2^{\text {nd }}$ edition. Cambridge University Press. 392 pages.

Lal, R. (2001). Soil degradation by erosion. Land degradation and Development, Vol.12, pp. 519 $-539$.

Lino, J. S. (2010) Evolução do sistema plantio direto e produção de sedimentos no Rio Grande do Sul. MSc Dissertation. Universidade de São Paulo (Piracicaba - SP - Brazil), 118 p.

Lopes-Assad, M. L.; Hamada, E.; Lana, J. T. O. (2009). Álgebra de mapas de atributos de solos para estimativa da aptidão agrícola das terras. In: XIV Brazilian Symposia of Remote Sensing, pp. 3479-3486.

Mendonça-Santos, M. L.; Santos, H. G. (2007). The state of the art of Brazilian soil mapping and prospects for digital soil mapping, p. 39 - 54. In P. Lagacherie, P., McBratney, A.B., Voltz, M. (Editors). Digital soil mapping: an introductory perspective. Elsevier Developments in Soil Science, volume 31. Amsterdam.

Moore, I.; Burch, G. (1986). Physical basis of the length-slope factor in the Universal Soil Loss Equation. Soil Science Society of America Journal, Vol.50, pp. 1294-1298.

Morgan, R. P. C.; Nearing, M. A. (2011). Handbook of Erosion Modelling. Wiley-Blackwell Publishing Ltd. West Sussex, UK, 398 p.

Mongkolsawat, C.; Thirangoon, P.; Sriwongsa, S. (1994). Soil erosion mapping with Universal Soil Loss Equation and GIS. GIS Development. URL: http://www.gisdevelopment.net/aars/acrs/1994/ts3

Nam, P. T.; Yang, D.; Kanae, S.; Oki, T.; Musiake, K. (2003). Global soil loss estimate using Rusle model: the use of global spatial datasets on estimating erosive parameters. Geoinformatics, Vol.14, pp. 49 - 53.

Palm, C.; Sanchez, P.; Ahamed, S.; Awiti, A. (2007). Soils: A Contemporary Perspective. Annual Review of Environmental Resources, Vol.32, pp. 99-129.

Presbitero, A. L.; Rose, C. W.; Yu, B.; Ciesiolka, C. A. A.; Coughlan, K. J.; Fentie, B. (2005). Investigation of Soil Erosion from Bare Steep Slopes of the Humid Tropic Philippines. Earth Interactions, Vol.9, pp. 1-30.

Rao, V. B.; Cavalcanti, I. F. A.; Hada, K. (1996). Annual variation of rainfall over Brazil and water vapor characteristics over South America. Journal of Geophysical Research, Vol.101, pp. 539-551.

Terranova, O.; Antronico, L.; Coscarelli, R.; Ianquita, P. (2009). Soil erosion risk scenarios in the Mediterranean environment using RUSLE and GIS: an application model for Calabria (Southern Italy). Geomorphology, Vol.112, pp. 228-245.

Theobald, D. M. (2007). GIS Concepts and ArcGIS Methods. 3 ${ }^{\text {rd }}$ ed. Fort Collins: Conservation Planning Technologies. 439 p.

Tornquist, C. G.; Mielniczuk, J.; Cerri, C.E.P. (2009). Modeling soil organic carbon dynamics in Oxisols of Ibiruba (Brazil) with the Century Model. Soil and Tillage Research, Vol.105, pp. 33-43.

Sayre, R; Bow, J.; Josse, C.; Sotomayor, L.; Touval, J. (n. d.). Terrestrial Ecosystems of South America. Publication available at Association of American Geographers. Access: April / 2011. URL: http://www.aag.org/galleries/nalcs/CH9.pdf

Silva, A. M. (2004). Rainfall erosivity map for Brazil. Catena, Vol.57, pp. 251-259. 
Silva, A. M.; Alvares, C. A. (2005). Levantamento de informações e estruturação de um banco de dados sobre a erodibilidade de classes de solos no Estado de São Paulo. Geociências, Vol.24, pp. 33-42.

Soares, A. (2006). Geoestatística para ciências da terra e ambiental. 2nd ed. IST Press, Lisboa, Portugal.

Soil Survey Staff. (1999). Soil taxonomy: a basic system of soil classification of making and interpreting soil surveys. 2nd. USDA-Natural Resources Conservation Service, Washington, D.C., USA (USDA. Agriculture Handbook, 436).

Sparovek, G.; Schnug, E. (2001). Temporal erosion-induced soil degradation and yield loss. Soil Science Society American Journal, Vol.65, pp. 1479-1486.

USDA (United States Department of Agriculture) (2003). Water Erosion Vulnerability Map. Access: April/2011. http:// soils.usda.gov/use/worldsoils/mapindex/erosh2o.html

Verspecht, A.; Vandermeulen, V.; De Bolle, S.; Moeskops, B.; Vermang, J.; Van den Bossche, A.; Van Huylenbroeck, G.; De Neve, S. (2011). Integrated policy approach to mitigate soil erosion in West Flanders. Land Degradation and Development, Vol.22, pp. 84-96.

Vieira, S.R. (2000). Geoestatística em estudos de variabilidade espacial do solo. P. 1-54. In: Novais, R.F. Alvarez V.V.H.; Schaefer, C.E.G.R., eds. Tópicos em Ciência do Solo. Brazilian Society of Soil Science, Viçosa, MG, Brazil.

Vieira, S.R.; Millete, J.; Topp, G.C.; Reynolds, W.D. (2002). Handbook for geostatistical analysis of variability in soil and climate data. p. 1-45. In: Alvarez V., V.H.; Schaefer, C.E.G.R.; Barros, N.F.; Mello, J.W.V.; Costa, L.M., eds. Tópicos em ciência do solo. Brazilian Society of Soil Science, Viçosa, MG, Brazil.

Vrieling, A.; Sterk, G.; Beaulieu, N. (2002). Erosion risk mapping: A methodological case study in the Colombian Eastern Plains. Journal of Soil and Water Conservation, Vol.57, pp. $158-163$.

Waswa, F.; Gachene, C.K.K.; Eggers, H. (2002). Assessment of erosion damage in Ndome and Ghazi, Taita Taveta, Kenya: towards an integrated erosion management approach. GeoJournal, Vol.56, pp. 171-176.

Wischmeier, W. H.; Smith, D. D. (1978). Predicting rainfall erosion losses. A guide to conservation planning. Supersedes Agriculture Handbook n 282. Science and Education Administration, United States Department of Agriculture.

Yue-Qing, X.; Xiao-Mei, S.; Xiang-Bin, K.; Jian, P.; Yun-Long, C. (2008). Adapting the RUSLE and GIS to model soil erosion risk in a mountains karst watershed, Guizhou Province, China. Environment Monitoring Assessment, Vol.141, pp. 275-286.

Valerio Filho, M. (1994). Técnicas de geoprocessamento e sensoriamento remoto aplicadas ao estudo integrado de bacias hidrográficas, p. 223 - 242. In Pereira, V. P., Ferreira, M. E., Cruz, M.C.P. Solos Altamente suscetíveis à erosão. FCAV - UNESP and SBCS. Jaboticabal - SP, 253 pages.

Zuquette, L.V.; Pejon, O. J.; Collares, J.Q. (2004). Land degradation assessment based on environmental geoindicators in the Fortaleza metropolitan region, state of Ceará, Brazil. Environmental Geology, Vol.45, pp. $408-425$.

Zimback, C.R.L. (2001). Spatial analysis of soil chemical attributes for mapping of fertility. UNESP/FCA, Botucatu, SP, Brazil. 


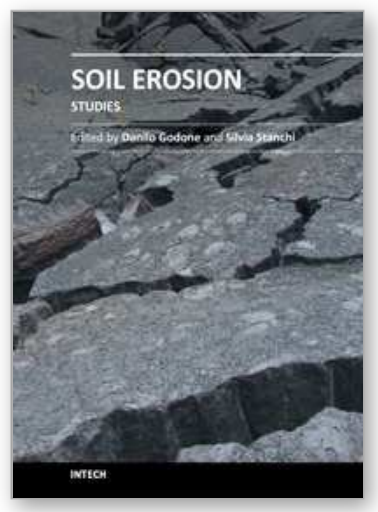

\author{
Soil Erosion Studies \\ Edited by Dr. Danilo Godone
}

ISBN 978-953-307-710-9

Hard cover, 320 pages

Publisher InTech

Published online 21, November, 2011

Published in print edition November, 2011

Soil erosion affects a large part of the Earth surface, and accelerated soil erosion is recognized as one of the main soil threats, compromising soil productive and protective functions. The land management in areas affected by soil erosion is a relevant issue for landscape and ecosystems preservation. In this book we collected a series of papers on erosion, not focusing on agronomic implications, but on a variety of other relevant aspects of the erosion phenomena. The book is divided into three sections: i) various implications of land management in arid and semiarid ecosystems, ii) erosion modeling and experimental studies; iii) other applications (e.g. geoscience, engineering). The book covers a wide range of erosion-related themes from a variety of points of view (assessment, modeling, mitigation, best practices etc.).

\title{
How to reference
}

In order to correctly reference this scholarly work, feel free to copy and paste the following:

Alexandre Marco da Silva, Clayton Alcarde Alvares and Claudia Hitomi Watanabe (2011). Natural Potential for Erosion for Brazilian Territory, Soil Erosion Studies, Dr. Danilo Godone (Ed.), ISBN: 978-953-307-710-9, InTech, Available from: http://www.intechopen.com/books/soil-erosion-studies/natural-potential-for-erosion-forbrazilian-territory

\section{INTECH}

open science | open minds

\section{InTech Europe}

University Campus STeP Ri

Slavka Krautzeka 83/A

51000 Rijeka, Croatia

Phone: +385 (51) 770447

Fax: +385 (51) 686166

www.intechopen.com

\section{InTech China}

Unit 405, Office Block, Hotel Equatorial Shanghai

No.65, Yan An Road (West), Shanghai, 200040, China

中国上海市延安西路65号上海国际贵都大饭店办公楼405单元

Phone: +86-21-62489820

Fax: +86-21-62489821 
(C) 2011 The Author(s). Licensee IntechOpen. This is an open access article distributed under the terms of the Creative Commons Attribution 3.0 License, which permits unrestricted use, distribution, and reproduction in any medium, provided the original work is properly cited. 